\title{
The impact of changing market requirements on dock labour employment systems in northwest European seaports
}

\author{
Theo E. Notteboom \\ China Institute of FTZ Supply Chain, \\ Shanghai Maritime University, \\ 1550 Haigang Avenue, Shanghai, 201306, China \\ and \\ Faculty of Law, \\ Maritime Institute, \\ Ghent University, \\ Universiteitsstraat 4, 9000 Gent, Belgium \\ and \\ Faculty of Applied Economics, \\ University of Antwerp, \\ Prinsstraat 13, 2000 Antwerpen, Belgium \\ and \\ Antwerp Maritime Academy, \\ Noordkasteel Oost 6, 2030 Antwerpen, Belgium \\ Email: theo.notteboom@gmail.com
}

\begin{abstract}
This paper contributes to existing dock labour literature by presenting a market-driven perspective on the organisation of dock work in light of changing market requirements. We conceptualise how changing market requirements affect the characteristics and the design of dock labour employment systems in seaports. The demand for a high dock labour performance is decomposed into three underlying dimensions: labour productivity, cost efficiency and more qualitative factors such as labour flexibility and service delivery. The internal organisation of dock labour takes place within a wider setting of legal and social conditions and the state of technology. Using the conceptual framework, we analyse how terminal operators try to meet changing market requirements through the deployment of new technology and advances in dock labour organisation. We provide empirical evidence by zooming in on the evolution of dock labour arrangements and employment systems in a number of northwest European ports.
\end{abstract}

Keywords: dock labour; labour performance; productivity; Europe; market dynamics.

Reference to this paper should be made as follows: Notteboom, T.E. (2018) 'The impact of changing market requirements on dock labour employment systems in northwest European seaports', Int. J. Shipping and Transport Logistics, Vol. 10, No. 4, pp.429-454. 
Biographical notes: Theo E. Notteboom is a Professor in Port and Maritime Economics and Management. He is a Research Professor at the China Institute of FTZ Supply Chain at Shanghai Maritime University. He holds a Chair Professorship 'Port of Ghent' at the Ghent University in Belgium. He also is a part-time Professor at the University of Antwerp and the Antwerp Maritime Academy in Belgium. He is immediate past President and council member of International Association of Maritime Economists (IAME). $\mathrm{He}$ is the Co-Director of Porteconomics.eu, a knowledge dissemination platform on port studies.

\section{Introduction}

Seaports are increasingly functioning not as individual places that handle ships but as turntables within global supply chains and global production networks (Notteboom and Winkelmans, 2001; Robinson, 2002). Pallis et al. (2011) point out that scholars have devoted an increasing number of studies on the role of ports in supply chains. The role of dock workers in the competitiveness of seaports and the impact of structural changes in the maritime and logistics market environment on dock labour requirements have not received a lot of attention in academic literature. Existing studies on dock labour tend to focus primarily on the social dimension such as the role of labour unions and the need for social dialogue (see e.g., Turnbull, 2006a; Turnbull and Wass, 2006). There is room for a more economic and market-driven approach of the organisation of dock work in light of changing market requirements.

The research question of this paper is as follows: To what extent and along which lines do the changing market requirements affect the characteristics and the design of dock labour arrangements and employment systems? To answer this question, we first introduce a conceptual framework on the market requirements of market players with respect to dock labour arrangements. This framework helps to conceptualise how changing market requirements affect the characteristics and the design of dock labour employment systems in seaports. The resulting aim of terminal operators to reach a high dock labour performance is decomposed into three underlying dimensions: labour productivity, cost efficiency and more qualitative factors such as labour flexibility and service delivery. The internal organisation of dock labour takes place within a wider setting of legal and social conditions and the state of technology. Next, using the conceptual framework as a guide, we analyse how terminal operators try to meet changing market requirements through the deployment of new technology and advances in dock labour organisation. We provide empirical evidence on the identified trends and changes by analysing the evolution of dock labour arrangements and employment systems in several northwest European ports. 


\section{Market requirements with respect to dock labour}

\subsection{Conceptual framework}

Figure 1 presents a conceptual framework following a market-driven approach on dock labour. The framework intends to capture the linkages between the key requirements of market actors and the resulting impact on demands in terms of dock labour performance. Shipping companies, third-party logistics service providers and shippers impose certain logistics requirements on ports and terminals based on the characteristics and the needs of supply chains. Terminals operators are challenged to meet these market requirements if they want to attract cargo and ships. The production factor dock labour and the associated dock labour deployment systems and arrangements have a role to play in meeting market requirements. Each textbox in Figure 1 was given a capital letter from A to H. References to these letters are made throughout the following sections.

Figure 1 Conceptual framework - the impact of changing market requirements on dock labour (see online version for colours)

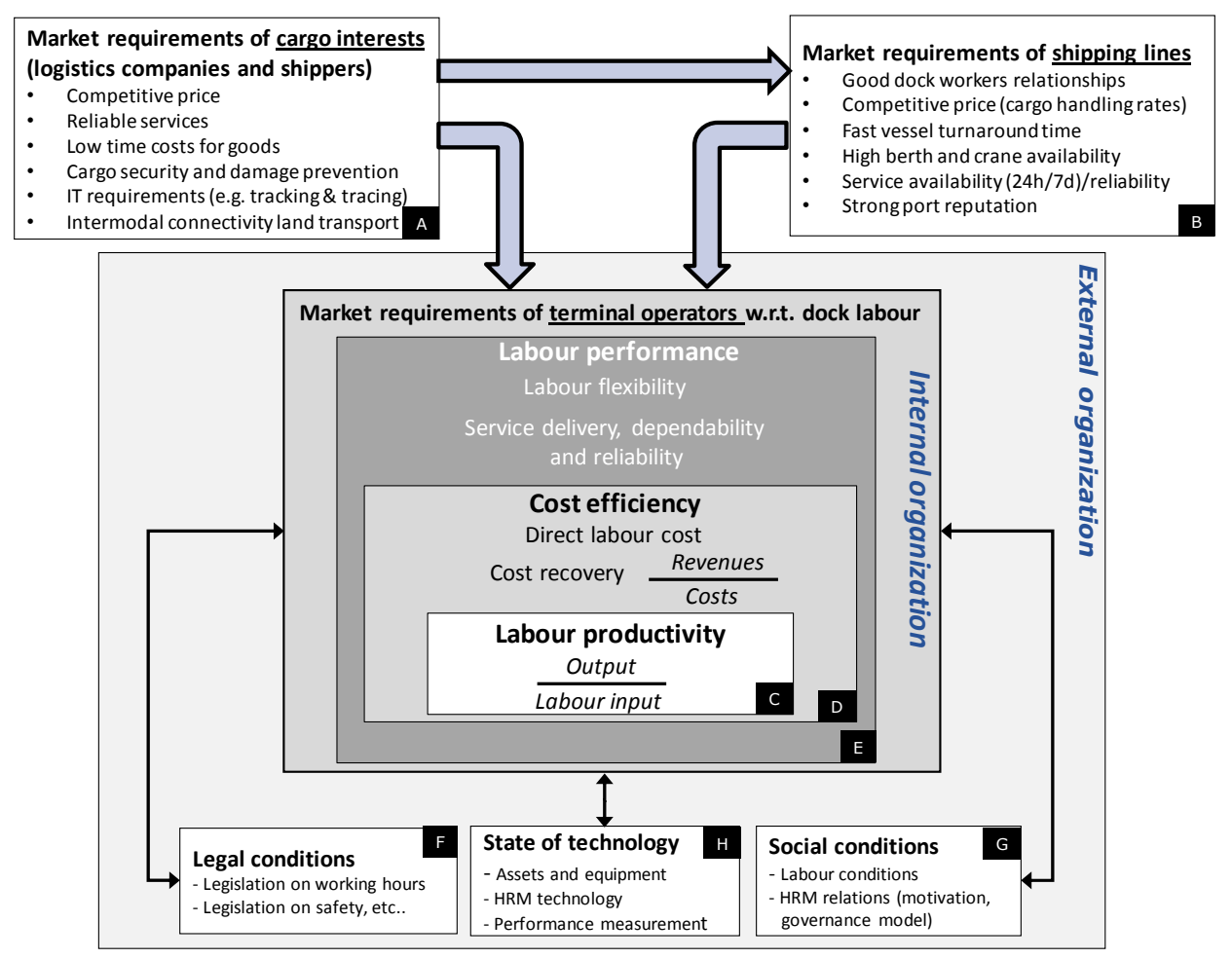

Source: Own compilation 
Table 1 Empirical results on the importance of selection criteria to shipping lines - Likert scale from 1 to 5

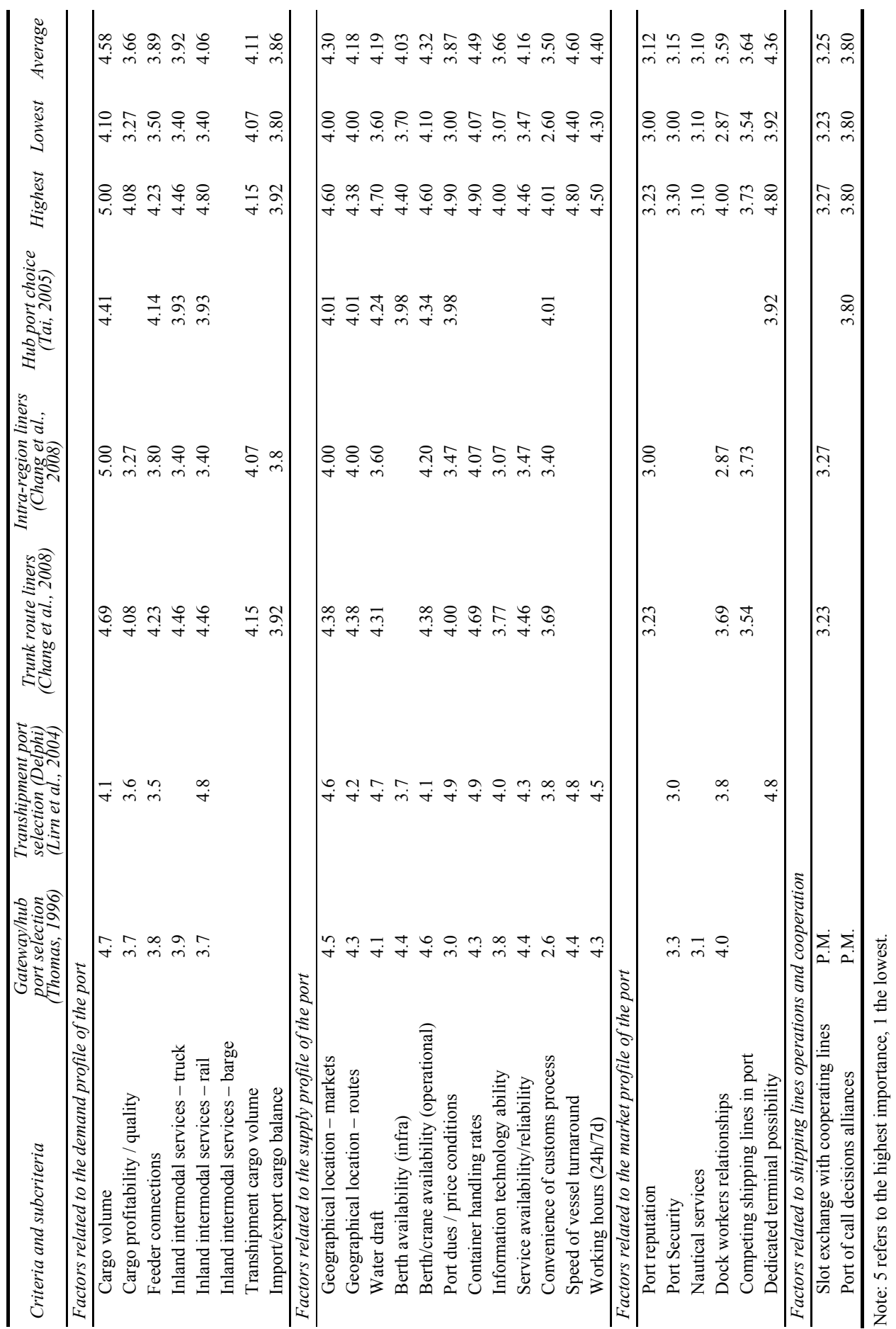




\subsection{The market requirements of cargo interests and shipping lines (boxes $A$ and $B$ in Figure 1)}

There is not a lot of literature dealing with port and terminal requirements of shippers and third-party logistics service providers. Most academic papers focus on modal choice and carrier selection by these market actors, instead of port selection (Lam and Dai, 2012). Changes in supply chains have forced ports and terminals to seek effective integration in these supply chains when delivering value to shippers and third-party logistics service providers (Robinson, 2002; Mangan et al., 2008). Song and Panayides (2008) provide a conceptual contribution to the measurement and quantification of such integration efforts. From existing literature, we can extract and deduce the main market requirements of logistics companies and shippers (Nir et al., 2003; Tiwari et al., 2003): a competitive price of port services, reliable services, low time costs for goods, cargo security and damage prevention, facilitation using information platforms and a good intermodal connectivity to the hinterland (box A in Figure 1).

The direct impact of shippers and other cargo interests on terminal operators depends on the commodity and type of terminal activity. For example, in the container business there typically are no contractual arrangements between terminal operators and shippers (or their representatives such as freight forwarders), so the market demand is exerted indirectly via the shipping lines who have contractual arrangements with the terminal operators. Figure 1 captures this complexity by showing two outgoing arrows linked to cargo interests, i.e., one going directly to terminal operators and one passing via shipping lines.

The port and terminal requirements of shipping lines are well documented in extant literature [see for example, the literature overviews provided in Tongzon and Sawant (2007), Wiegmans et al. (2008) and Lam and Dai (2012)]. In line with the port/terminal selection framework presented by Notteboom (2009), we distinguish four distinctive groups of selection factors relevant to shipping lines: factors related to the demand profile of the port or terminal, the supply profile, the market profile and shipping lines operations and cooperation. Table 1 gives an overview of the sub-criteria for each of the four main groups. The figures relate to the weights resulting from a selection of four much-cited empirical studies. The score range is from 1 to 5 , with 5 representing the highest score.

Dock labour is part of the supply profile of the port or terminal. Dock worker relationships are listed as a separate port/terminal selection criterion. However, dock labour performance also has an impact on a lot of other criteria. For example, impacts might be found in relation to supply profile factors such as container handling rates, service reliability, speed of vessel turnaround and berth availability. Factors related to the market profile of the port can also be strongly affected by dock labour performance. For example, a dock worker strike negatively affects the factor port reputation. Furthermore, dock labour can have effects on inland transportation, particularly in ports where rail and barge cargo is handled by registered dock workers.

\subsection{Market requirements of terminal operators with respect to dock labour (boxes $C$ to $E$ )}

Dock labour is a key production factor for terminal operators, next to terminal land and capital goods such as cranes, yard equipment and terminal management system hardware 
and software. The terminal operator business is marked by waves of consolidation and the entrance of global terminal operators such as PSA, HPH, DP World and APM Terminals in the container business (Bichou and Bell, 2007; Olivier et al., 2007). In addition, large logistics players and multinational enterprises get increasingly involved in terminal operations as exemplified by investments of steel groups in bulk terminals (e.g., German steel groups Thyssen Krupp Stahl and Hüttenwerke Krupp Mannesmann are the full owners of the EECV terminal in Rotterdam; ArcelorMittal has own terminal facilities at many of its maritime steel plants), the setting-up of dedicated forest products terminals (e.g., StoraEnso) or the development of specialised fruit terminals (e.g., Dole, Chiquita). Even commodity traders such as Glencore and Trafigura are investing in terminal facilities (Meersman et al., 2013). In the above cases, a shipper or a shipping line also acts as terminal operator which leads to a direct intra-organisational link between the market requirements of shipper/shipping line and terminal operator. Large port customers and large cargo handling companies can exert a significant impact on dock labour arrangements as they try to apply best practices throughout their terminal network (Parola et al., 2015).

Shippers, third-party logistics service providers and shipping lines exert pressure on terminal operators to meet their market requirements (Figure 1). The requirements of these market actors push terminal operators towards a maximisation of the performance of dock workers. This objective can be decomposed in three underlying dimensions, i.e., labour productivity, cost efficiency and more qualitative aspects of labour performance (boxes $\mathrm{C}, \mathrm{D}$ and $\mathrm{E}$ in Figure 1). These dimensions are part of the 'internal' organisation as they are largely under the control of the dock labour management actors. Dock labour arrangements and systems should be designed in such a way that dock workers meet the market needs. However, these internal dimensions related to the organisation of dock work take place within a wider setting of legal and social conditions (boxes $F$ and $G$ in Figure 1) and the current and future state of technology (box H). These more external dimensions are not under the control of the dock labour management actors and form framework conditions for the development of dock labour systems. In the next sections, we discuss each of the segments of market requirements of terminal operators in view of explaining their meaning and demonstrating how they interact.

\subsubsection{Dimensions of labour performance: labour productivity (box C)}

Labour productivity (box $\mathrm{C}$ in Figure 1) is a narrow economic interpretation of labour performance and can be defined as total output divided by labour inputs (Samuelson and Nordhaus, 1989). Labour productivity captures the extent to which the human capital is delivering value to the firm. The dock labour input quantity can typically be expressed in number of man hours worked and or the size of the docker workforce deployed to handle cargo. The output quantity can relate to the cargo volume handled per time unit (i.e., an hour, shift, week, month or year) and or the created value added for the terminal operating company. In a supply chain context, the value added of dock labour is the enhancement added to the supply chain by the workforce of the terminal operating company. From an accounting point of view value added is the sum of wages, amortisations of capital goods and loss/profits. With the increasing importance of integrating ports and terminals in value-driven supply chains (Robinson, 2002), many ports and terminal operators have developed a stronger interest in the creation of 
value-added, next to the more traditional approach aimed at the maximisation of cargo tons handled (Carbone and Martino, 2003; Loyen, 2004; Paixão and Marlow, 2003)

When using the output per man hour or tons per gang shift, one should consider the technology used to handle the cargo and the nature of the cargo (Hamark, 2014). Benchmarking dock labour productivity thus requires indicators which combine handling rates with the technology used, for instance by looking at output per man hour produced with a certain stock of fixed capital of a given technology and operational characteristics, as suggested by Haralambides (1995). A high productivity per vessel (e.g., tonnage loaded and discharged per shift) is not always associated with a high productivity per dock worker (i.e., tonnage loaded and discharged per dock worker per shift) as the outcome is strongly dependent on the number and size of the gangs and the number and type of cranes and other equipment deployed to handle the vessel. The identification and use of relevant measures and key performance indicators (KPIs) on labour productivity also poses challenges in other industries where capital-intensive assets are used to produce outputs in the form of products or services (Datta et al., 2005).

\subsubsection{Dimensions of labour performance: cost efficiency (box D)}

Cost efficiency is the second dimension of labour performance (box D in Figure 1). Based on a survey among a sample of terminals in northwest Europe, Notteboom (2010) found that dock labour costs (blue collar) typically represent between $40 \%$ and $75 \%$ of total terminal operating costs of general cargo terminals. Next to a base wage, the labour costs include bonuses and wage supplements which are widespread in the port industry. Even in the capital-intensive container handling industry, the share of dock labour costs in total operating costs can be as high as $50 \%$. The handling of dry bulk (i.e., major bulks such as iron ore and coal) requires less dock labour due to the existence of conveyor belt systems throughout the bulk terminals. The share of labour costs in total operating costs at dry bulk terminals therefore typically ranges between $15 \%$ and $20 \%$ (Notteboom, 2010).

Cost recovery is an important consideration for terminal operators in the context of labour cost efficiency. To reach cost recovery, terminal operators should design terminal pricing schemes that generate revenues above the total fixed and variable terminal operating costs related to capital, land and labour (i.e., dock workers and white collar workers involved in terminal management and administration). Terminal operators strive for high operating margins and thus a high return on investment. For example, Beard (2015) reported that the Earnings Before Interest, Taxes, Depreciation and Amortization (EBITDA) margin (i.e., EBITDA divided by total revenue) for the ten largest global container terminal operators fluctuated between $20 \%$ and $50 \%$ in the period $2009-2014$, while the top ten container shipping lines recorded very volatile EBITDA margins ranging from $-30 \%$ to $20 \%$ in the same period. Alphaliner (2014) shows that the EBITDA margins in 2013 for 17 global and more regional container terminal operators ranged from $20 \%$ to $55 \%$, The newest terminal pricing schemes go beyond pure cost recovery by encouraging productive behaviour of the shipping lines (Glave and Saxon, 2015), for instance by rewarding shipping lines who show a high on time arrival track record of their vessels. 


\subsubsection{Dimensions of labour performance: qualitative aspects (box E)}

The performance dimensions of labour productivity and cost efficiency are affected by the more qualitative aspects of labour flexibility, and service reliability, quality and dependability (box E in Figure 1). A low service reliability, quality and dependability (i.e., the quality of being able to be counted on or relied upon) of dock workers exposes terminal operators and the wider maritime and logistics community to all sorts of indirect and unanticipated costs and can negatively affect productivity and cost recovery targets.

First, the service reliability is undermined when there is a shortage of gangs or dock workers leading to substantial delays in vessel loading and discharging operations. Shortages can be caused by sudden non-anticipated peaks in demand or a (short-term) significant drop in the availability of dock workers (due to holiday period, weekends). Structural long-term shortages are an incentive to enlarge the docker workforce.

Second, service quality is partly reflected in damage free terminal operations. Cargo damage incidents at the terminal can result in an interruption of the normal operations and generate costs for the cargo owner. A high incidence of damage cases might point to a lack of training or a low commitment of the dock worker (i.e., the absence of a 'we care' attitude).

Third, strikes negatively affect service reliability, quality and dependability. Short isolated strikes and long port-wide strikes by dock workers reduce labour productivity (sometimes to zero) and impose costs on the port and logistics community which can trickle down to an entire economic system. Strikes cause port deviation costs for shipowners, time costs for ships in port, lost revenues for inland transport operators and other port-related companies, time costs and broader logistics costs for cargo owners and potentially high costs to factories linked to major disruptions in the production line (stock-out). Strikes are typically a result of disputes about labour conditions with potentially detrimental long-term effects on the port's reputation. The history of the port industry has been earmarked by labour disputes. Most of the time, strikes were the result of disputes between labour unions (representing the interests of the dock workers) and employer organisations with respect to the terms and conditions for the renewal of collective bargaining agreements.

Fourth, accidents and absenteeism can confront a port or terminal with service reliability challenges, lower productivity and additional costs. Terminals and ports might be confronted with absenteeism or the failure of workers to report when they are scheduled to work. The reasons for absenteeism can be company-related (e.g., ineffective selection and placement procedures, excessive fatigue, ineffective use of skills, poor supervision, inadequate training or promotion programs, etc.) or personal causes (e.g., dual occupation, alcoholism or drugs). As in other industries, absenteeism can relate to job satisfaction, but also as an indicator of worker's responsibility in fulfilling his/her contractual obligations.

Finally, a lower service quality can also be the result of operational inefficiencies due to a lack of communication between the vessel and the terminal, possible breakdowns of equipment or the late reception of the load plans. These will in the end affect cost efficiency and labour productivity.

Next to service reliability, quality and dependability concerns, there are the needs of terminal operators in terms of labour flexibility which has many faces. First there is flexibility in working hours. A distinction should be made between passive and active flexibility. Passive flexibility implies that the employer establishes schedules considering 
legal provisions and breaks, holidays, etc. Active flexibility gives a lot of initiative to the employee. A dock labour employment system with many casual workers normally generates a high degree of active flexibility. The dock workers have, within certain limits, a freedom of choice for certain tasks. When the dock labour employment system does not impose a work obligation at specific moments in time (for example, for weekend work or work on holidays) finding enough volunteers is often a matter of providing generous bonuses for performing such tasks.

Secondly, there is flexibility in terms of the total labour quantity. This refers to the possibility to adapt the size of the workforce to the amount of work that needs to be done. In terminal operations that suffer from peaks in cargo handling demand, this kind of flexibility is crucial for a good business operation. There is also another dimension linked to this type of flexibility: the possibility to recruit workers outside of a dock workers pool (for instance, via temporary labour offices) when there are shortages.

A third type of flexibility refers to the operational deployment of dock workers or the extent to which dock workers can be used for different types of tasks (multi-skilling or multi-tasking). When dock workers are assigned to specific job categories then such flexibility is only guaranteed when a system of qualifications (based on certification or training) allows dock workers' mobility between categories. When dock workers strictly adhere to their specific professional category then the multi-skilled nature over the categories is typically low. This can lead to discrepancies whereby shortages in one category cannot be compensated by surplus dockers in other (higher ranked) categories. The multi-skilling flexibility of a dock worker can also relate to a particular professional category. For example, a driver who can be deployed both at a paper terminal (forklift equipped with a paper clip) and a banana terminal (forklift equipped to deal with four pallets simultaneously). A multi-skilling orientation of dock workers' classifications can be helpful when the port is confronted with large cargo flows with a highly cyclicality or seasonality. For example, dock workers of a given category who normally are deployed on a fruit terminal can shift during the low season to other terminals which might be confronted with cargo peaks.

Finally, there is flexibility in the assignment of gangs/teams, the size of the gangs and the shift system in place. In principle, the employers benefit the most when they have the widest possible freedom in switching gangs between vessels during a shift, to vary the size of the gangs to match the desired productivity per hour and to deploy every dock worker to work in the most appropriate shift. In practice, there are limits to such forms of flexibility. Vidaček et al. (1986) and Folkard and Tucker (2003) show that workers doing night shifts or confronted with regular changes between night and day shifts show a lower labour productivity. There are also legal provisions on working and resting times and the provisions stipulated in local dock labour schemes.

\subsection{The external organisation: legal and social conditions and state of technology (boxes $F$ to $H$ )}

The internal organisation of dock labour is taking place within a wider setting of legal and social conditions (boxes $F$ and $G$ in Figure 1) and the state of technology (H). The legal constraints are embedded in regulation and legislation and industry-wide labour and safety regulations. Both national governments and international/supranational organisations such as the International Labour Organization (ILO) have a role to play. 
Meletiou (2006) offers a good overview of the port-related conventions, recommendations, guidelines and manuals developed by ILO. One port-related ILO convention is the Dock Work Convention (No. 137) of 1973, a convention on the social repercussions of new methods of cargo handling in docks. This convention assigns great importance on the worker-technology relationship in ports and particularly on the issues of efficiency and training. More specifically, Article 5 states that national policy should encourage cooperation between employers or their organisations, on the one hand, and workers' organisations, on the other hand, in improving the efficiency of work in ports, with the participation, as appropriate, of the competent authorities. Moreover, Article 6 stipulates that each member shall ensure that appropriate safety, health, welfare and vocational training provisions apply to dockworkers. The ILO Occupational Safety and Health (Dock Work) Convention (No. 152) of 1979 includes several mandatory requirements regarding training. ILO also brings out recommendations which set out guidelines, which can orient national policy and action and often complement corresponding conventions.

The theme of social conditions, including labour relations, is complex, difficult to delineate and hard to measure. From a social perspective, a dock labour employment system should seek motivation and work spirit among the dockers. As early as the 1960s scholars argued that the longshore industry, because of its peculiar nature, should be considered as a separate labour market (see e.g., Weinstein, 1963). While dock labour is confronted with specific labour challenges not commonly found in many other industries (e.g., manpower utilisation, job security, flexibility, demand fluctuations, etc.), we do not go so far in trying to disconnect dock labour from the principles guiding labour deployment in other industries. As is the case in other industries, dockers feel best when they can rely on structures that defend their interests. Often these structures are organised not at company level but at the level of the whole port or the whole industry. Dock workers have a strong preference for employment systems that combine job freedom with labour conditions that are found in permanent contracts (such as job security and guaranteed wages).

The overall state of technology determines to what extent terminal operators can deploy new technology to improve the three dimensions of dock labour performance. These new technologies can be applied in the areas of terminal management, terminal equipment and automation, performance measurement and management and human resource management (e.g., electronic hiring systems for dock workers).

\section{Meeting the market requirements with respect to dock labour}

\subsection{Methodological approach}

In addressing the research question 'To what extent and along which lines do the changing market requirements affect the characteristics and the design of dock labour arrangements and employment systems?', this section analyses how terminal operators try to meet changing market requirements. Figure 2 which is an extension of Figure 1, summarises how terminal operators can meet the changing market requirements. In general terms, terminal operators try to improve the underlying dimensions of dock labour performance and thus meet the market requirements by deploying new technology 
and by pushing for changes in the organisation of dock labour in the ports in which they are active.

Figure 2 The role of dock labour arrangements and systems in meeting market requirements (see online version for colours)

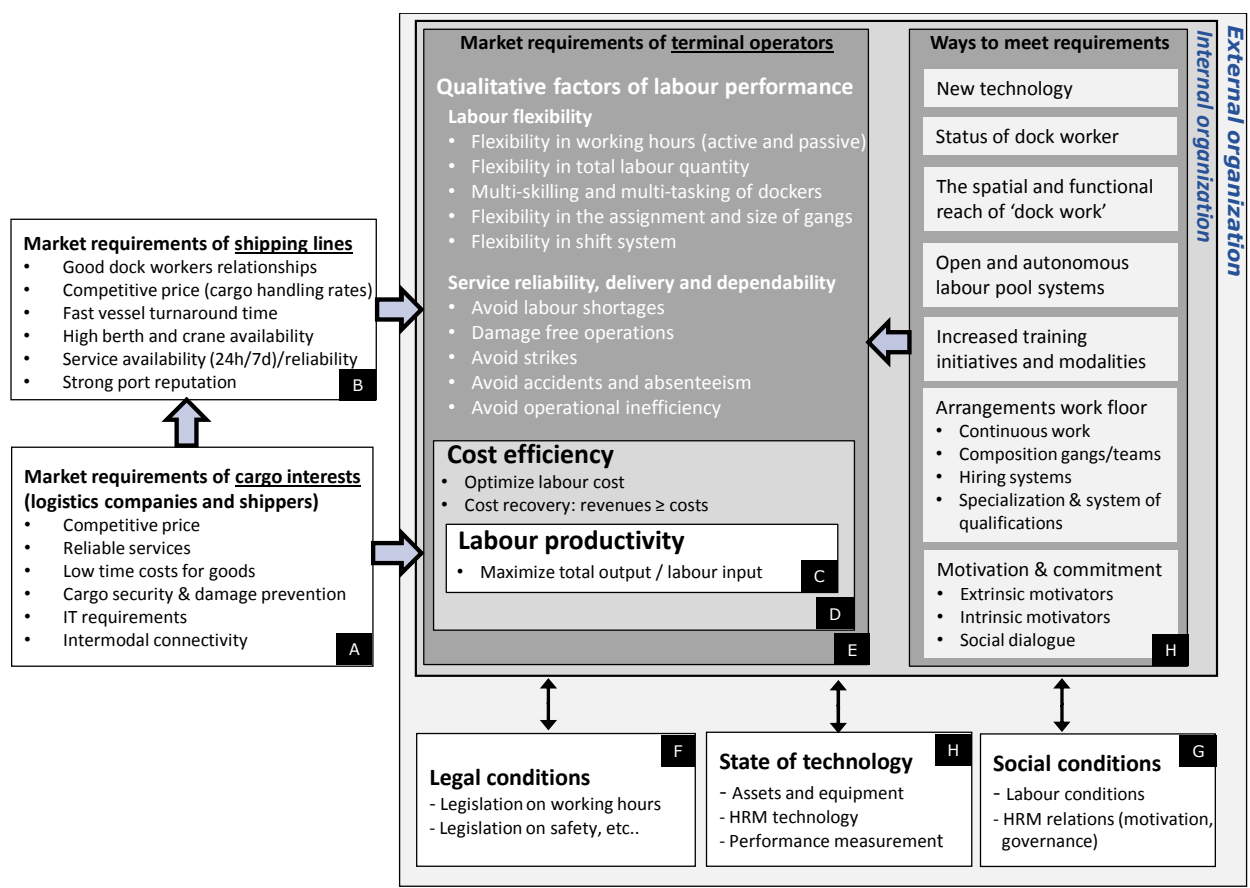

Strategic management literature underlines that the way in which an organisation manages its human resources has a perceptible and significant relationship to the productivity of its employees (Koch and McGrath, 1996). In a dock labour context, terminal operators do not always have full management control over their dock-related human resources, for example, in case of the compulsory use of a port-wide dock labour pool. Furthermore, the internationalisation in the cargo handling industry facilitates the transfer of technologies and human resources practices over a wide range of ports, but also affects the traditional patronage structures in ports. Decades-old relationships between incumbent terminal operators and dock worker groups can be scrutinised by newcomers who want to implement their best practices regarding dock labour. In some cases, traditional patronage structures conflict with the needs of a modern terminal management, making changes in employee-employer relations and the dock labour employment system unavoidable. However, different countries and ports adopted quite different approaches to reform processes. For example, the British Government clearly chose for a 'big bang' approach when abolishing the National Dock Labour Scheme in 1989, while other countries have followed a more 'incremental' approach based on a continuous evolution (not revolution) in existing dock labour arrangements. 
Table 2 Key steps in dock labour reform processes in a number of northwest European ports

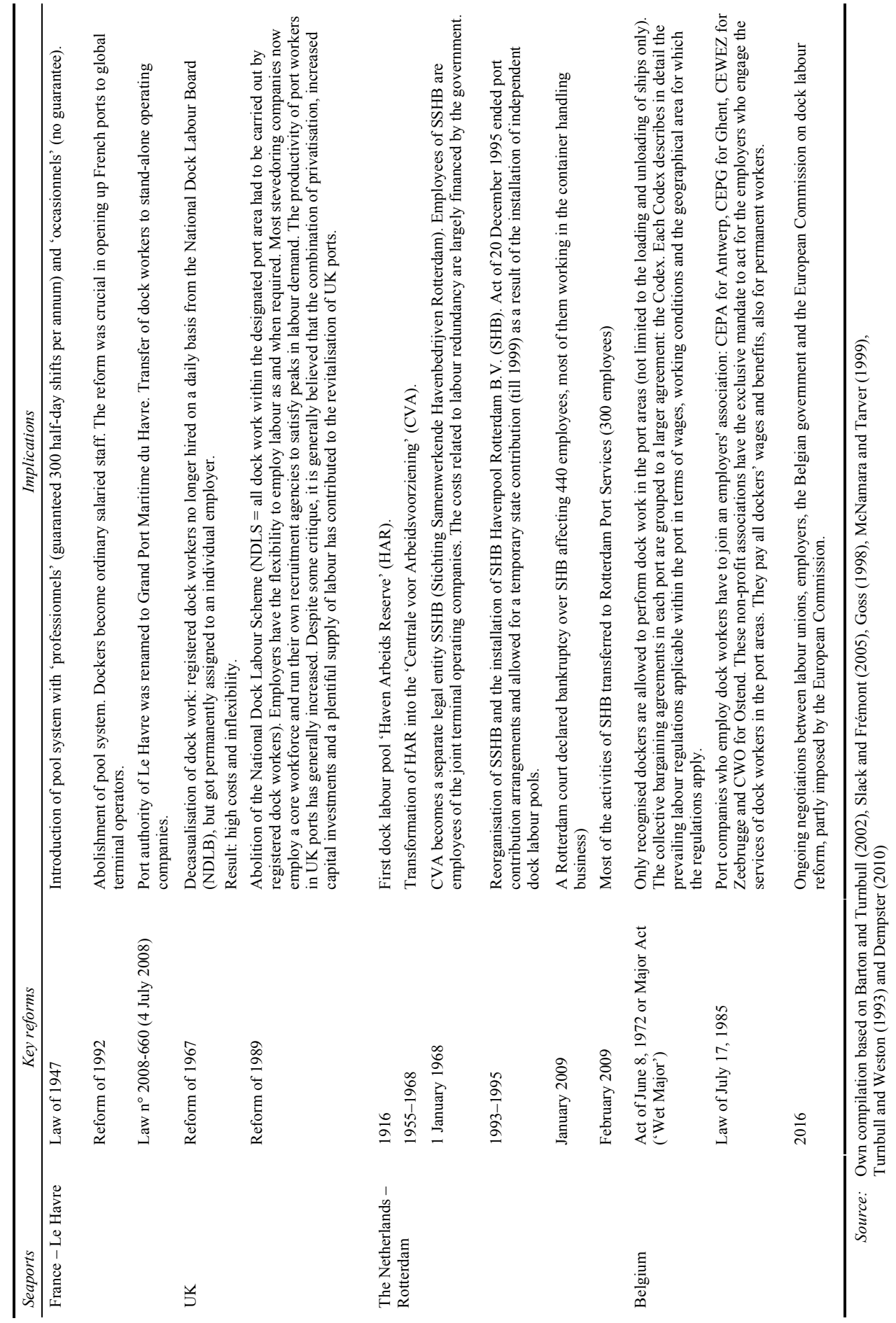


Table 3 Comparison of dock labour arrangements in a number of northwest European ports

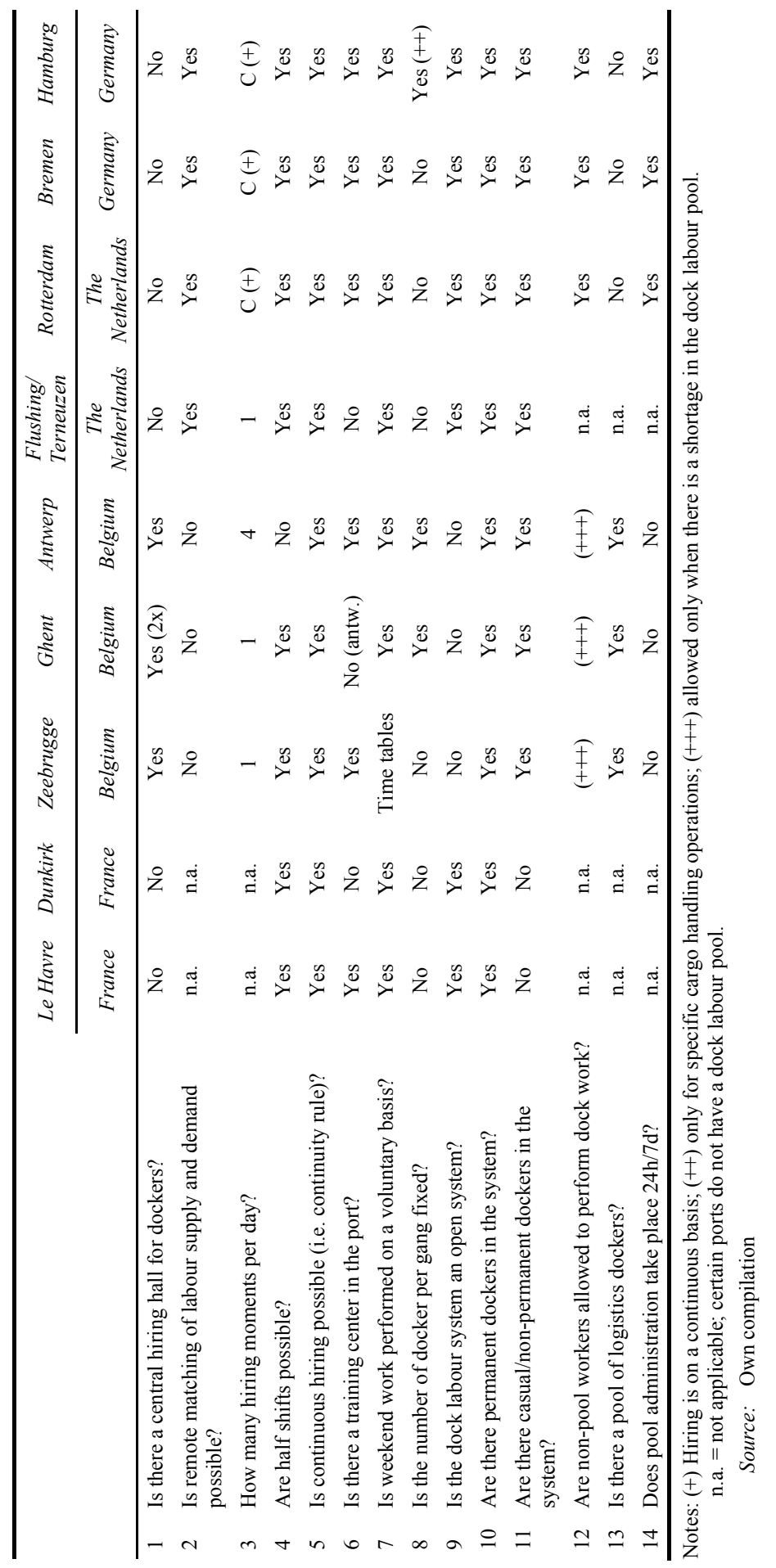


In the following sections, we discuss each of the key changes and trends in terminal technology and the organisation of dock work listed in Figure 2. We support the discussion by using empirical evidence on northwest European ports. The empirical insights were gradually acquired throughout the period 2009-2016 based on existing academic literature, articles in the written press and specialised business magazines, and information obtained from terminal operators and dock worker organisations in the respective ports (i.e., documentation made available and non-structured interviews and exchanges with representatives of these companies and organisations) in the framework of several projects on dock labour. Tables 2 and 3 provide empirical information which will be used in the further discussions. Table 2 summarises the key steps in dock labour reform processes in several northwest European countries and ports. Table 3 provides an overview of some more operational arrangements linked to existing dock labour employment systems in northwest European ports.

\subsection{The deployment of new technology}

The use of advanced terminal equipment and planning technology is one way for terminal operators to increase terminal performance and meet market requirements. Technological advances in cargo handling facilities led to labour productivity increases and quality improvements, but also brought new requirements in terms of the skills and qualifications of the workforce. Until the Second World War, dock work basically required no or little previous training, except for the operation of the simple mechanical devices (e.g., forklift) which at that time accounted for something like $10 \%$ of the work (Jensen, 1964; Hamark, 2014). The arrival of unit loads such as containers and pallets increased the need for dock workers who have the qualifications and experience to operate more specialised handling superstructure. A whole new range of crane drivers, straddle carrier drivers and drivers of other equipment emerged requiring the development of new and different skills through training. Whether these new technologies imply dock workers are now more skilled than before remains debatable, as mechanisation can lead to a gradual loss of some more manual cargo handling and stowage skills (see e.g., Miller, 1969; Green, 2000; Turnbull, 1992).

Technological innovations and developments in cargo handling increase labour productivity expressed in tons handled per docker per time unit (box $\mathrm{C}$ in Figure 2). A typical example is the unloading of bananas. Only a decade ago, toboggans cranes (crane equipped with a movable arm and a conveyor system) were quite common to discharge individual banana boxes one by one from the hold of a reefer ship. Today, banana boxes transported by reefer vessels are palletised and handled by specially equipped pallet cages attached to a crane. The system allows to unload up to eight pallets in one move. Reefer containers are also commonly used which adds to labour productivity. With the introduction of pallet cages and containerisation the number of banana boxes handled per minute per crane increased from 50 when using a toboggans crane to 385 for the pallet cage and 480 when pallets are containerised.

The relation between technology and cost efficiency (box D in Figure 2) depends on the benefit/cost ratio of investments in new terminal technology. The willingness of stevedoring companies to invest in new cargo handling technology and automation is partly related to the perceived labour productivity benefits and cost savings at the level of dock labour. If a technical innovation would in principle allow to reduce the manpower per gang (or in case of full automation, even eliminate manpower) then the terminal 
operator will only benefit from the labour cost savings if the gangs are indeed reduced in size. If such a reduction in manpower is not possible within the contours of the dock labour employment system, then the stevedoring company will be far less eager to introduce technological innovations. The trade-offs that need to be made when introducing new automated cargo handling technology clearly surfaced in a recent dispute between labour unions and terminal operator APM Terminals in the port of Rotterdam. The newest terminal of APM Terminals features remotely controlled ship-toshore cranes as the company believes automation can take out much of the human disruption on reliable terminal productivity linked to the handling of ever larger container vessels (Nightingale, 2015). The new terminal development faced strong opposition from labour unions as they feared possible loss of jobs and lower wages given the shift from classical crane drivers to remote operators of automated cranes.

\subsection{The (legal) status of the dock worker}

Dock workers can be civil servants in state-owned service ports, workers directly employed by a private terminal operating company or workers employed through dock labour schemes. Quite a few dock labour employment systems require that only registered dock workers can perform dock work in the port (for example, the Act Major in Belgian ports, see Table 2). This obligation can be imposed by national or regional legislation or might also be the outcome of collective bargaining agreements between port employers and trade unions. Though not ratified by a lot of Member States, Article 3 of ILO Convention 137 makes explicit reference to the registration of dock workers: "Registers shall be established and maintained for all occupational categories of dock workers, in a manner to be determined by national law or practice" and "Registered dock workers shall have priority of engagement for dock work". In those ports where employers must use registered dock workers, the criteria to recognise dock workers and the entities involved in the recognition process might differ among ports. Port reform processes often envisage to loosen the preferential relations between registered dock workers and port employers, and to introduce competition among providers of registered dock work services.

European labour unions are strongly against self-handling defined as 'a situation in which a port user provides for itself one or more categories of port services' [Commission of the European Communities, (2001), p.28]. Self-handling can involve cargo handling operations by shipping lines' own staff, seafarers or hired non-recognised dockers from employment agencies or other sources of labour supply. The discussion on self-handling is considered crucial for ensuring the future of registered dockers. In the past, labour unions have (successfully) fought against two proposals of the European Commission on a Directive on Market Access to Port Services (also known as Port Package I of 2001 and Port Package II of 2004) primarily because they aimed at allowing self-handling (Turnbull, 2006a; Verhoeven, 2010). Self-handling jeopardises dockers' jobs and the unions consider cargo handling operations as highly dangerous operations that can only be done by trained and experienced workers. The European Transport Federation (ETF) launched a European-wide campaign in May 2015 to put an end to self-handling cases in lashing and unlashing operations (European Transport Workers' Federation, 2016). ETF is determined to enforce clauses in collective bargaining agreements for seafarers stating that lashing needs to be done by dockers. 


\subsection{The spatial and functional reach of 'dock work'}

In most northwest European ports, dock labour is confined to the loading and unloading of ships within the port area. The development of logistics activities in ports led to discussions on the reach of the definition of 'dock work'. For example, the port of Le Havre was hit by docker strikes in 1999 partly on the grounds that new logistics work should be classified as 'dock work'.

At present, only Belgian ports are confronted with a very broad spatial and functional application of dock labour including all forms of cargo handling in a designated port area, including warehousing, stuffing and stripping, loading and unloading from inland waterway vessels, trucks, railway wagons, etc (see item 13 in Table 3). To keep the Belgian ports competitive in view of attracting logistics activities, a special (cheaper) category of dock workers was created to work in port-related warehouses. Registered dock workers are now categorised into two separate groups, namely the General Contingent and the Logistics Contingent (in Antwerp via the law of December 19, 2000 and in Zeebrugge via the Royal Decree of July 5, 2004). Dock workers of the Logistics Contingent perform dock labour in locations where, in preparation of the further distribution or forwarding of the goods, the latter undergo a transformation resulting indirectly in identifiable added value. These latter dock workers are contracted by an employer on a permanent basis. The categorisation allowed for separate remuneration conditions, recognition procedures and working conditions for each of the two categories of dock workers as contained in the collective bargaining agreements. A similar arrangement exists in the port of Ghent.

\subsection{More open and autonomous labour pool systems}

A large variety in dock labour schemes can be observed among northwest European ports. Ports can depend on a dock labour scheme based on a centrally managed pool of registered dock workers. The use of registered dockers through a pool can be mandatory or not. This obligation can be de facto or imposed by law. By the 1960s or 1970s, many major ports had institutionalised, by law or by governmentally supported collective bargaining, organised systems for limiting competition in the dock labour market. The schemes generally involve three elements:

a the designation of an 'in-group' of officially registered (in effect, licensed) dock workers

b registered workers are not permanently employed at particular stevedoring enterprises, but hired through a central pool or hiring hall, which stevedores are obligated to use for their primary source of casual labour

c a system of minimum pay guarantees or unemployment benefits for registered dockworkers who are left idle by a shortage of ships to be worked during a particular day, week or month.

One of the main incentives behind the establishment of dock labour pools in quite a few ports is to guarantee flexibility in labour quantity. Employers and employees then jointly determine the size of the docker workforce based on current and future needs.

Most dock labour reforms have led to small or significant changes to labour pool arrangements in the sense that the matching of labour supply and demand in the port was 
altered (Table 2). In an increasing number of ports, dock workers are directly employed by terminal operators, instead of contracted via pools. In some cases, such as in Germany and the Netherlands, employers can hire permanent company employees directly from the external labour market, but any additional (casual) labour must be hired from a regulated labour pool. A labour pool can be organised in the form of an (autonomous) undertaking that provides labour services to port operators or workers in a pool can be hired by these operators. There is a general trend towards open and autonomous pool systems with back-up of temporary employment agencies. Over the last 50 years or so, the collective bargaining process in many ports has progressively been decentralised to the company level. In some cases, reforms have privatised the status and operation of labour pools (e.g., in the Netherlands in 1995, see Table 2). Dock labour employment systems in Dutch ports are now governed by collective bargaining agreements. Most of the collective bargaining agreements stipulate that the port employer shall only use its permanent dock workers or the dock workers of a labour pool for activities that fall under the collective bargaining agreement. Since the port employers face some cyclicality and unpredictability in cargo flows, they have worked on setting up a flexible system combining permanent employees (who have a labour contract with one terminal operator) and casual workers linked to a labour pool (see item 11 in Table 3).

Open labour pools also exist in Germany. The Gesamt Hafenbetriebs Gesellschaft (GHB) is the largest provider of port-related workers in the port of Hamburg. The 'Unternehmensverband Hafen Hamburg', an association of port companies, holds $97 \%$ of the shareholding of GHB. GHB provides a flexible work force to companies who are dealing with peaks in port demand. The port workers in the GHB can be used virtually in all sectors and are generally well trained. GHB can also function as transfer point for surplus dock workers. Companies can offer excess capacity to the pool, but the pool is not obliged to take it. GHB works according to the $7 \mathrm{~d} / 24 \mathrm{~h}$ principle. In Bremen/Bremerhaven, similar to the Hamburg case, an independent pool was established now functioning under the name Gesammt Hafen Betriebs Verein im Lande Bremen E.V. (GHBV). Also, this pool consists of well-trained dock workers who can be deployed for all kinds of port activities. GHBV guarantees a minimum guaranteed income regardless of the level of employment. Besides the pool of dock workers there is also a backup system in place based on 'rote Karte': casual workers who are standby to fulfil temporary assignments. These employees are mostly students and unemployed people who followed a course, received minimum general safety training and are subject to a selection test. This category of people is mainly used in warehouse operations, absorbing peak activity, and for conducting logistical tasks.

The status of dock labour pools and the degree of openness of some of these pools remain points of attention and contention in European port circles. When referring to pool systems the European Commission in its Communication on a European Port Policy (Commission of the European Communities, 2007) stated that "the treaty rules on freedom of establishment and freedom to provide services can fully apply to the activities carried out by the pools" and that "such arrangements should not be used to prevent suitably qualified individuals or undertakings from providing cargo-handling services, or to impose, on employers, workforce that they do not need, since this could under certain circumstances fall foul of the Treaty rules on the Internal Market, and in particular of Article 43 on freedom of establishment and Article 49 on freedom to provide services" [see also Jerman (2009) and Verhoeven (2010) for detailed insights]. 
In April 2016, the European Commission made the decision to refer Spain to the Court of Justice of the EU for failing to comply with an earlier ruling of the Court concerning the freedom of establishment at Spanish ports (European Commission, 2016). It states that some of the obligations for terminal operators in Spanish ports go against Article 49 of the Treaty on the Functioning of the European Union (TFEU), i.e., the obligations to register with a pool company, to hold shares in that company and to employ, as a priority, workers provided by that company. At the time of writing, Spain did not adequately follow-up on the court's decision which could result in financial penalties on Spain. The European judgment is important as it demonstrates that the European Commission is determined to make an end to any closed dock labour employment systems. Considering the above, the de facto closed labour pool system in Belgian ports is also under scrutiny by the European Commission. Ongoing negotiations on dock labour reform between the labour unions, employers, the Belgian Government and the European Commission are expected to result in a more open labour pool system with more room for third-party providers of dock work to enter the market.

\subsection{Increased training initiatives and modalities}

Labour performance is impacted by training and experience levels. A customised training plan can provide dock workers with a future career path based on experience and proven competence. Many ports use occupational categories of dock workers combined with clear rules regarding the flow from one category to another higher category. The regulation of the influx of new dockers is also relevant in this context. Key issues in this respect relate to the 'screening' of potential candidates, training facilities, the modalities for trial periods and the characteristics of labour evaluation systems.

Many ports have set up dedicated training centres for dock workers (item 6 in Table 3). The port of Rotterdam provides a structured training program for its workers. Before any person can work in the port he or she had to attend an approved course at the Port Training College, which is run by the port transport industry in collaboration with the Rotterdam Port Employee's Association, trade unions, the municipal authority and government. In France, some port operators organise training sessions to avoid accidents and damages and to enhance labour productivity. In Belgian ports, employers' associations, such as CEPA in Antwerp, take responsibility for port-wide training, ensuring high levels of competency across the entire labour force. The training centres offer obligatory professional training courses for newly registered dockers and special schooling for dockers willing to move to another job category. A last example is GHBV in Bremen. GHBV has its own training facilities and provides training for its workers' pool, in consultation with port companies.

\subsection{Arrangements at the work floor: a push for continuous work}

Terminal operators are pushing for changes in labour arrangements in view of boosting labour productivity, cost efficiency, service quality and labour flexibility. A first consideration is a push for continuous work to meet the service availability $(24 \mathrm{~h} / 7 \mathrm{~d})$ and reliability requirements of shipping lines. Scale increases in vessel size exert strong pressure on terminals in terms of the vessel turnaround time in port (see also box B in Figure 2). The high time costs of vessels make a high quay productivity and $24 \mathrm{~h} / 7 \mathrm{~d}$ operations indispensable. Dock workers are increasingly challenged to yield performance 
improvements in terminal operations. While the pace of change differs among northwest European ports, there is a general tendency towards individual rather than collective breaks, flexible start times and variable shift lengths. In some ports, there are still strict limitations in this area. For example, half shifts or continuous hiring (starting a shift at a preferred moment in time) are not possible in Antwerp (see items 4 and 5 in Table 3). Under certain conditions, half shifts and slight changes to shift hours are possible in Zeebrugge and Ghent. Dock labour schemes show various ways in dealing with overtime, night shifts and weekend work. For example, in some ports weekend work is to some extent considered as a normal shift, while dockers in other ports have the freedom to accept weekend shifts (voluntary basis) with provisions in place for overtime money in case they do (see item 7 in Table 3). In Zeebrugge, about $85 \%$ of the dockers work following a 'timetable system' which also includes weekend work. Employers allocate port workers for a certain period. The dockers have to attain an average number of shifts during that period. The remaining $15 \%$ of workers have to come to the hiring hall (unemployment possible).

Another trend is the implementation of the so-called 'hot seat' change or the seamless transition from one shift to another which results in continuous work on a ship thereby reducing idle time of the handling equipment.

\subsection{Arrangements at the work floor: composition of gangs or teams}

Specific arrangements at the level of the organisation at the work floor matter in the context of labour performance. The gang system in place provides a good example. A competitive spirit between dock worker gangs and a strong social control within a gang enhance labour performance per shift. Strong and highly motivated foremen typically create an atmosphere of coherence and a focus on strong team work. A high flexibility in the deployment of gangs (e.g., movement of a gang between vessels during a shift) also contributes to an optimal use of available dock workers.

Northwest European ports show a rather large variety in the way the respective dock labour employment systems deal with the composition of and flexibility within gangs or teams of dockers. There are systems advocating semi-autonomous and multi-skilled team-working with a high degree of freedom given to the teams to allocate tasks within specific shifts and over longer shift cycles. Other ports strongly rely on rather fixed gangs (see item 8 in Table 3 ) as the central entities responsible for achieving a high productivity through experience, team-work and a spirit of competition among the gangs.

\subsection{Arrangements at the work floor: changes in hiring systems}

The hiring methods are guided by the provisions of local dock labour schemes. Even in ports with a pool of registered dock workers, hiring systems can vary greatly in terms of

a the hiring moment (e.g., hiring at fixed moments per week day or on a continuous basis, see items 3 and 5 in Table 3)

b the persons involved in the hiring process (e.g., foreman, company officials)

c the characteristics and governance of the supervisory system 
d the interaction between docker and hiring person/entity (e.g., physical in a hiring hall or via electronic systems, see item 1 in Table 3)

e the control given to the docker (e.g., matching on a voluntary basis or controlled externally with or without taking into account the preferences of dockers, see item 2 in Table 3).

Technological advances in mobile communication have facilitated the modernisation of job assignment systems towards electronic dispatching of dock workers in ports or terminals which have a high demand for a flexible work force. The use of physical hiring halls is becoming rare, but still exists in Belgian ports. Despite the existence of a common legal framework in Belgium (Major Act), there are quite a few differences between the hiring system for casual dockers as stipulated by the local port regulations (Codex), see Table 3. Employers in the port of Antwerp are bound to fixed shift hours (day, morning, afternoon and night shift) connected to four daily sessions at a central hiring hall. Ghent has two hiring sessions per weekday, Zeebrugge only one. However, about two thirds of all casual dockers in Antwerp are effectively quasi-permanent or semi-regular, working for the same employer on a regular basis via a 'repeat hiring' by a regular employer. Casual dockers value the idea that they can return to the hiring hall whenever they like, even when many of them work as semi-regulars and seldom visit the hiring hall. When demand is low, terminal operators can return surplus dockers to the hiring hall. The guaranteed payments, for casuals dockers and returned semi-regular dockers confronted with a short or prolonged period of unemployment, are mainly financed by the state via an unemployment benefit and partly also by the employers via a special fund.

\subsection{Arrangements at the work floor: specialisation, categorisation and qualification of dock workers}

Terminal operators are pushing for changes in the specialisation, categorisation and qualification of dock workers in view of increasing labour flexibility. Dockers in ports are generally not a homogenous group. Significant differences between their members can relate to the tasks carried out, the required skills, the way they are hired, the training arrangements, career planning, etc. One of the foundations for categorisation of dock workers is the division between permanent and non-permanent workers (see items 10 and 11 in Table 3). Global terminal operators, particularly in the container business, increasingly demand direct employment for a significant number of their own workers, especially crane drivers and other operators of heavy yard equipment (the regulars). Casual workers are deployed during periods of peak demand. Even when a labour scheme is in place that includes a pool of registered casual workers, local port employers often hire a large part of the dockers on an almost continual basis (the quasi-permanent workers or semi-regulars). Labour schemes often include a 'continuity rule' (see item 5 in Table 3): a docker hired on a particular day can be rehired for the next day(s) without having to be rehired every one of these days in a central hiring place (the principle of 'repeat hiring'). The rule also gives the chance to new dock workers to become acquainted with the routines in a gang.

Some labour systems rely on a system of job categories of dockers, with varying degrees of labour mobility between categories. Other employment systems are based on job qualifications, allowing a (casual) docker to be deployed for any dock work if he has 
the right qualification(s). Dock labour employment systems show various types and degrees of multi-skilling among dockers. The multi-skilling programs can be organised at company-level, by the pool or provided for by the state. Multi-skilling arrangements in some cases allow functional combinations of several jobs to be performed within the same shift which adds to labour flexibility.

There is a push of terminal operators to move away from job categories and to opt for job qualification systems. A first example is the dock labour organisation in Flushing and Terneuzen (managed by Zeeland Seaports) which is characterised by a high degree of flexibility. People with the right qualification have access to the profession of dock worker. The high degree of flexibility is also reflected in the recruitment of casual dockers, the deployment of multi-skilled dock workers (exchange of workers between different terminals during a shift), the composition of the gangs, etc. Terminal operating companies largely rely on permanent dockers paid according to the collective bargaining agreement at company level. Wage differentiation is based on three elements: qualifications, seniority and bonuses/surcharges. The peaks in port demand can be absorbed through casual workers made available via temporary labour offices such as Tense Logistics and Labour Services Zeeland. Casual workers sign contracts with these labour offices and work according to the conditions contained therein (hourly wage, working hours, leave, allowances, etc.). The terms and provisions of the contracts between the casual worker and the temporary labour office apply (such as the start of a shift or shift duration). Permanent and casual dock workers in Flushing and Terneuzen can only be deployed exclusively for quay-related tasks. Logistical tasks fall under the collective agreements which are concluded at company level.

A second example relates to the current classification of dock workers in French ports which depends on their role in the gang (foreman, quay leader, reach stackers drivers, etc.). The system allows for some flexibility in the tasks but the dispatch appoints as much as possible the dock workers according to their specialisation (i.e., role in the gang and commodity). Belgian ports use a system of job categories for permanent dockers such as a 'foreman' who oversees a gang, a 'ceelbaas' who oversees several gangs working on the same ship, the 'conterbaas' who is responsible for hiring casual dockers, chieftallyman, assistant chief-tallyman, container repairer and quay crane driver. The job categories of causal dockers include dockers 'general work', tallymen, deck men, 'minerai' men (for the handling of ores) and several categories of drivers of mechanical equipment. The job categories used in other Belgian ports differ only slightly. The many fixed job categories of dock workers, the limited mobility between job categories and the fact that dock workers are assigned to the same shift for longer periods of time reduce labour flexibility. A shortage in one job category and shift may not easily be compensated by surpluses in other categories or shifts. Next to a further opening of the labour pool system, the shift from job categories to job qualifications is another key element on the negotiation table in the ongoing discussions on a reform of the Belgian dock labour employment system.

\subsection{Enhancing motivation and commitment of dock workers}

Mitroussi and Notteboom (2015) discussed the intrinsic and extrinsic motivators that can be used in a dock labour context to promote motivation, a high labour spirit and commitment. Extrinsic motivators include wage levels and a performance-based bonus 
system in view of stimulating labour performance and job loyalty. For example, the most straightforward way to increase labour flexibility is to increase the remuneration of dock workers through higher base wages or, more commonly, by installing bonus systems linked to flexible tasking and irregular working hours. In quite a few ports, the remuneration for dockers is considered high when compared to other industries, particularly in the case of closed pool systems and strong union presence. At the same time, dockers who receive higher wages, such as in the port of Antwerp, are often cited for having a strong track record when it comes to labour productivity.

Among the intrinsic motivators, we find non-financial employment motivation and mental well-being aimed at increasing job satisfaction. When the societal status of the profession and professional pride are low, the port might face difficulties in finding motivated dock workers.

Workers' motivation and commitment is also impacted by the industry relations between employers and employees. A spirit of consultation and social dialogue enhances employee-employer relationships. Labour unions are typically very visible at the dock labour front, although major differences in union power can be observed across seaports and countries (Turnbull and Wass, 2006). Trade unions are well organised in Belgium, the Netherlands, Germany and France. While differences exist with respect to how and at what institutional level collective bargaining agreements are negotiated, the trade unions in these ports generally form a united front at the national level, the regional level, in the ports and at a port-company level. Most of the northwest European ports have a long tradition of social dialogue, both via formal and informal channels. Dock workers are often very direct in formulating their opinions, both internally during union meetings as towards others. Negotiators thus require specific skills in terms of understanding the differences in negotiating tactics and styles of trade unions and employers. In case of disputes, a disputes-resolution procedure sets in to resolve problems and to avoid strikes. Social dialogue through effective bodies of joint consultation is considered as the key to a sustainable relation between employers and trade unions. A climate of constructive dialogue enhances social peace in ports. In 2005, the International Labour Organization published a practical guide to social dialogue in the process of structural adjustment and private sector participation in ports (Turnbull, 2006b).

\section{Conclusions}

Cargo handling operations lie at the core of the raison d'être of ports and contribute to a port's competitiveness. Dock labour arrangements and employment systems have an important role to play in this context. Still, the impact of recent changes in the market environment of ports and terminals on the requirements with respect to dock labour remains a largely under-researched theme in the field of maritime studies. This paper contributes to existing dock labour literature by presenting a market-driven perspective on the organisation of dock work in light of changing market requirements. The presented conceptual framework links key requirements of shippers, logistics service providers and shipping lines to the resulting demands of terminal operators with respect to dock labour performance and its three underlying dimensions. This framework was further enriched in Figure 2 by including the primary means used by terminal operators to meet changing market requirements, i.e., the deployment of new technology and specific advances in dock labour organisation. The obtained insights on the relationships between market 
requirements, dock labour performance and dock labour arrangements and employment systems provide a labour-oriented contribution to extant literature on the changing role of ports and terminals in supply chains.

The changing market requirements affect the characteristics and the design of dock labour employment systems in multiple ways. While the pace of change differs among northwest European ports, current market dynamics have opened discussions on and have led to changes in the legal status of the dock worker, the spatial and functional reach of the definition of dock work and the functioning of labour pools. There is a push towards more open and autonomous pool systems with back-up of temporary employment agencies. We observed a general tendency or push from the employers' side towards continuous working, flexible start times and variable shift lengths. Container terminal operators are opting more and more for permanent workers. In quite a few ports with a labour pool, the 'continuity rule' via the principle of 'repeat hiring' is gaining in importance. Such arrangements created quasi-permanent or semi-regular dockers. Northwest European ports continue to show a rather large variety in the way the respective labour systems deal with the composition of and flexibility within gangs or teams of dockers. An increasing number of labour pools are based on job qualifications, allowing a (casual) docker to be deployed for any dock work for which the right qualification(s) have been granted. Seaports with labour systems based on job categories are pushed towards higher degrees of labour mobility between categories or a system of job qualifications. Increasing labour performance is not only a matter of having dockers work harder but also to work smarter (Meletiou, 2006). Working smarter in a port context can be achieved by eliminating unnecessary tasks, developing a strong sense of teamwork, providing continuous training or giving workers more say about how to do their jobs and in problem solving. Psychosocial factors are a major source of performance improvements in the port sector.

Our research supports the idea that terminal operators cannot only focus on hard economic issues when trying to improve labour performance. They also need to consider somewhat softer social aspects. The attention in this research for social dimensions such as motivation, commitment and the need for social dialogue does not contradict with the market-driven perspective developed in the paper. Market players need to consider these more social dimensions when aiming for a higher labour performance, as intrinsic motivators complement more extrinsic motivators (such as wages and bonuses).

Before concluding, the reader should be aware of several limitations of this study and avenues for future research. We developed a conceptual framework that identifies the relationships between market requirements, dimensions of labour performance and the role of technology and labour organisation in terminal operators' striving for a higher labour performance. The framework was empirically supported by evidence on the dynamics in dock labour employment systems in northwest European ports. However, the discussion remained largely qualitative in nature. The relationships have not been empirically quantified. We believe there is room for such a quantification, but this assumes that difficulties in obtaining non-publicly available data on dock labour performance can be overcome. Next, there is room for extending the port sample to other regions around the world. Such an exercise might reveal whether some sort of regionalism exists in the way dock labour arrangements and schemes respond and adapt to changing market requirements. In case regional differences do exist, a research stream could be developed to analyse the role of institutional, social, political and economic 
factors in explaining such differences. Pallis et al. (2011) and $\mathrm{Ng}$ et al. (2014) demonstrate that similar research efforts have been developed in recent years in view of examining the role of these factors in explaining regional differences in port performance and port management models.

\section{References}

Alphaliner (2014) 'APMT defend margin gap against global port operators', Alphaliner Weekly Newsletter, Vol. 23, No. 1-2.

Barton, H. and Turnbull, P. (2002) 'Labour regulation and competitive performance in the port transport industry: the changing fortunes of three major European seaports', European Journal of Industrial Relations, Vol. 2, No. 2, pp.133-156.

Beard, F. (2015) Transhipment in an Age of Mega-vessels and Mega-alliances - Can Ports Afford not to Play the Game?, 14 December, Presentation to China Merchants Holdings (International), Shenzhen.

Bichou, K. and Bell, M. (2007) 'Internationalisation and consolidation of the container port industry: assessment of channel structure and relationships', Maritime Economics and Logistics, Vol. 9, No. 1, pp.35-51.

Carbone, V. and Martino, M.D. (2003) 'The changing role of ports in supply-chain management: an empirical analysis', Maritime Policy \& Management, Vol. 30, No. 4, pp.305-320.

Chang, Y.T., Lee, S-Y., Tongzon, J., Chou, C.C., Chu, C.W. and Liang, G.S. (2008) 'Port selection factors by shipping lines: different perspectives between trunk liners and feeder service providers', Marine Policy, Vol. 32, No. 6, pp.877-885.

Commission of the European Communities (2001) Reinforcing Quality Service in Sea Ports: A Key for European Transport, Proposal for a Directive of the European Parliament and of the Council on Market Access to Port Services, COM 35 final, CEC, Brussels.

Commission of the European Communities (2007) Communication on a European Ports Policy, COM 616, CEC, Brussels.

Datta, D.K., Guthrie, J.P. and Wright, P.M. (2005) 'Human resource management and labor productivity: does industry matter?', Academy of Management Journal, Vol. 48, No. 1, pp.135-145.

Dempster, J. (2010) The Rise and Fall of the UK Dock Labour Scheme, Biteback Publishers, London.

European Commission (2016) Port Labour: Commission Refers Spain to the Court of Justice for the Second Time, 28 April, Press Release IP/16/1455, EC, Brussels.

European Transport Workers' Federation (2016) 'German dockers claim back lashing', ETF Dockers' Newsletter, 18 May.

Folkard, S. and Tucker, P. (2003) 'Shift work, safety and productivity', Occupational Medicine, Vol. 53, No. 2, pp.95-101.

Glave, T. and Saxon, S. (2015) How to Rethink Pricing at Container Terminals, December, McKinsey\&Company, Copenhagen.

Goss, R. (1998) 'British port policies since 1945', Journal of Transport Economics and Policy, Vol. 32, No. 1, pp.51-71.

Green, A. (2000) 'The work process', in Davies, S. et al. (Eds.): Dock Workers: International Explorations in Comparative Labour History 1790-1970 (Volumes I \& II), Ashgate, Aldershot.

Hamark, J. (2014) 'Technology and productivity in the port of Gothenburg C. 1850-1965', International Journal of Maritime History, Vol. 26, No. 2, pp.265-287.

Haralambides, H. (1995) 'Port structural adjustment and labour reform', Proceedings of the Seventh World Conference on Transport Research, Sydney, Australia. 
Jensen, V.H. (1964) Hiring of dock workers, Harvard University Press, Cambridge.

Jerman, B. (2009) Some Labour and Social Questions in the European Union Port Sector, Mimeo, Luka Koper.

Koch, M.J. and McGrath, R.G. (1996) 'Improving labour productivity: human resource management policies do matter', Strategic Management Journal, Vol. 17, No. 5, pp.335-354.

Lam, J.S.L. and Dai, J. (2012) 'A decision support system for port selection', Transportation Planning and Technology, Vol. 35, No. 4, pp.509-524.

Lirn, T.C., Thanopoulou, H.A., Beynon, M.J. and Beresford, A.K.C. (2004) 'An Application of AHP on transhipment port selection: a global perspective', Maritime Economics and Logistics, Vol. 6, No. 1, pp.70-91.

Loyen, R. (2004) 'From register tonnage to added value: the cautious advent of a new performance indicator', in De Goey, F. (Ed.): Comparative Port History of Rotterdam and Antwerp (18802000): Competition, Cargo and Costs, Aksant Academic Publ., Amsterdam, pp.215-241.

Mangan, J., Lalwani, C. and Fynes, B. (2008) 'Port-centric logistics', The International Journal of Logistics Management, Vol. 19, No. 1, pp.29-41.

McNamara, T.M. and Tarver, S. (1999) 'The strengths and weaknesses of dock labour reform - ten years on', Economic Affairs, Vol. 19, No. 2, pp.12-17.

Meersman, S., Rechtsteiner, R. and Sharp, G. (2013) 'The dawn of a new order in commodity trading', Risk Journal, Vol. 2, pp.1-9.

Meletiou, M. (2006) 'Improved port performance through training: the contribution of the International Labour Organization', 22nd International Port Conference on "Human Resources and Sea Ports Performance”, Alexandria, Egypt, 12-14 March.

Miller, R.C. (1969) 'The dockworker subculture and some problems in cross-cultural and crosstime generalizations', Comparative Studies in Society and History, Vol. 11, No. 3, pp.302-314.

Mitroussi, K. and Notteboom, T. (2015) 'Getting the work done: a comparative study on motivation needs and processes for seafarers and dock workers', WMU Journal of Maritime Affairs, Vol. 14, No. 2, pp.247-265.

Ng, A.K.Y., Ducruet, C., Jacobs, W., Monios, J., Notteboom, T., Rodrigue, J-P., Slack, B., Tam, K-C. and Wilmsmeier, G. (2014) 'Port geography at the crossroads with human geography: between flows and spaces', Journal of Transport Geography, December, Vol. 41, pp.84-96.

Nightingale, L. (2015) 'A new era in automation', Containerisation International, January/February, pp.40-42.

Nir, A-S., Lin, K. and Liang, G.S. (2003) 'Port choice behaviour - from the perspective of the shipper', Maritime Policy and Management, Vol. 30, No. 2, pp.165-173.

Notteboom, T. (2009) 'Complementarity and substitutability among adjacent gateway ports', Environment and Planning A, Vol. 41, No. 3, pp.743-762.

Notteboom, T. (2010) Dock Labour and Port-Related Employment in the European Seaport System: Key Factors to Port Competitiveness and Reform, p.87, ITMMA - University of Antwerp, Antwerp.

Notteboom, T. and Winkelmans, W. (2001) 'Structural changes in logistics: how will port authorities face the challenge?', Maritime Policy and Management, Vol. 28, No. 1, pp.71-89.

Olivier, D., Parola, F., Slack, B. and Wang, J. (2007) 'The time scale of internationalisation: the case of the container port industry', Maritime Economics and Logistics, Vol. 9, No. 1, pp.1-34.

Paixão, A.C. and Marlow, P. (2003) 'Fourth generation ports - a question of agility?', International Journal of Physical Distribution \& Logistics Management, Vol. 33, No. 4, pp.355-376.

Pallis, A., Vitsounis, T., De Langen, P. and Notteboom, T. (2011) 'Port economics, policy and management: content classification and Survey', Transport Reviews, Vol. 31, No. 4, pp.445-471. 
Parola, F., Notteboom, T., Satta, G. and Rodrigue, J-P. (2015) 'The impact of multiple-site acquisitions on corporate growth patterns of International Terminal Operators', International Journal of Shipping and Transport Logistics, Vol. 7, No. 5, pp.621-648.

Robinson, R. (2002) 'Ports as elements in value-driven chain systems: the new paradigm', Maritime Policy and Management, Vol. 29, No. 3, pp.241-255.

Samuelson, P.A. and Nordhaus, W.D. (1989) Economics, 13th ed., McGraw-Hill, New York.

Slack, B. and Frémont, A. (2005) 'Transformation of port terminal operations: from the local to the global', Transport Reviews, Vol. 25, No. 1, pp.117-130.

Song, D.W. and Panayides, P.M. (2008) 'Global supply chain and port/terminal: integration and competitiveness', Maritime Policy \& Management, Vol. 35, No. 1, pp.73-87.

Tai, H. (2005) 'Analysis of hub port choice for container trunk lines in East Asia', Journal of the Eastern Asia Society for Transportation Studies, Vol. 6, pp.907-919.

Thomas, B.J. (1996) 'The brand equity of European seaports: a survey on ship operators' image of and satisfaction with European seaport authorities and container terminal operators', Port Finance Conference, London.

Tiwari, P., Itoh, H. and Doi, M. (2003) 'Shippers' port and carrier selection behavior in China: a discrete choice analysis', Maritime Economics and Logistics, Vol. 5, No. 1, pp.23-39.

Tongzon, J.L. and Sawant, L. (2007) 'Port choice in a competitive environment: from the shipping lines' perspective', Applied Economics, Vol. 39, No. 4, pp.477-492.

Turnbull, P. (1992) 'Dock strikes and the demise of the dockers 'occupational culture', The Sociological Review, Vol. 40, No. 2, pp.294-318.

Turnbull, P. (2006a) 'The war on Europe's waterfront - repertoires of power in the port transport industry', British Journal of Industrial Relations, Vol. 44, No. 2, pp.305-326.

Turnbull, P. (2006b) Social Dialogue in the Process of Structural Adjustment and Private Sector Participation in Ports: a Practical Guidance Manual, International Labour Organization (ILO), Geneva

Turnbull, P. and Wass, V.J. (2006) 'Defending dock workers - globalization and labor relations in the world's ports', Proceedings of the 20th Conference of the Association of Industrial Relations Academics of Australia and New Zealand, pp.519-532.

Turnbull, P. and Weston, S. (1993) 'The British port transport industry. Part 2. Employment, working practices and productivity', Maritime Policy and Management, Vol. 20, No. 3, pp.181-195.

Verhoeven, P. (2010) 'Dock labour schemes in the context of EU law and policy', in Dempster, J. (Ed.): The Rise and Fall of the UK Dock Labour Scheme, Biteback Publishers, London.

Vidaček, S., Kaliterna, L., Radošević-Vidaček, B. and Folkard, S. (1986) 'Productivity on a weekly rotating shift system: circadian adjustment and sleep deprivation effects?', Ergonomics, Vol. 29, No. 12, pp.1583-1590.

Weinstein, P. (1963) 'The featherbedding problem', IRRA Proceedings of 16th annual Meeting.

Wiegmans, B.W., Van Der Hoest, A. and Notteboom, T. (2008) 'Port and terminal selection by deep-sea container operators', Maritime Policy and Management, Vol. 35, No. 6, pp.517-534. 